却器を通して混入している液狀物を分離し， $250^{\circ} \mathrm{C}$ に加 䓡してメタナイガーに通し, 驖䪅媒上で混つている一酸 化炭素をメタンに變え，一酸化炭素を完全に除いた後水 添工程の入口に洨る。

又第二反應塔下部より出した生成物は 10 atm. に落し て分離器に揆り，溶けたガスを除いた生成物は濾過機に 邆る。滤過機はバッチで行われ，常に空素氣流を流して むる。主成物の濾過が終ると新しい原料オレフィンを攄 過の方向とは逆に下から通し, 濾過機に殘つた䚡媒を原 料オレフィンに混ぜてこれをオキり主程に揆る。この間 の二工程を經て生成物を觸媒と分離し，分離した觸媒を 新しいオ゙レフィンに混ぜてもとのオキソ工程に揆るまで の一回循環に要する時間は原料オレフィン700 の場合 約一時間であると云われる。

次に濾過して觸媒を分離された生成物の精製は伐用し た原料オレフィンの種賎により暲なり，原料オレフィン の沸㷂範園が $30^{\circ} \mathrm{O}$ 以內の場合は蒸溜によりアルコール と末反應オレフィンとの分離が行かれるが，若し原料オ レフィンの沸點籍園が鹿い場合は明酸法によりアルコー ルの矹酸エステルにして分離される。

以上オキり反應並びにその工業的否用について述べた。 オキり法は現在では工業的に筫く利用され種々の製品が 大規模に生產されている樣であるが，反應機構に關する 詳細なる研究は未だ㱠んど行なわれておらず現在では假 定の段階に過ぎない。

最後に原稿の一噸を煩わし，耗々御注意を賜わつた見 玉信次郎教授に感謝の意を表する次第である。

(昭利 27 作?月 4 日受理)

\section{女 献}

1) D. F. Smith et al., J. Am. Chem. Soc., 52, 3221 (1930).

2) O. Roelen, U. S. P., 2327066 (1943).

3）兒王信次郎，最近の化學とその應用，第二集，p. 118.

4）日比野英一，高是瓦斯協會誌， 15,91 (昭和 26).

5) H. H. Storch, Chem. Eng. Progress, 44, 477 (1948).

W. J. Sparks et a1., Ind. Eng. Chem., 41, 665 (1949).

W. F. Gresiam et al., U. S. P., 2437600 (1948).

P. Spijker et al., U. S. P., 2486693 (1949).

6) G. M. Whitman., U. S. P., 2462448 (1949).

7) W. Sherwood Petroleum Processing, 4, 794 (1649). J. T. Harlan, U. S P., 2504682 (1950).

8) H. Adkins et al., J. Am. Chem. Soc., 70, 383 (1948).

9) 兒玉信次郎，日化總會講演 (昭和 27 ).

10) A. I. M. Keulemans et al,. Rec. Trav. Chim., 67, 298 (1948).

11) J. W. Copenhaver, Acetylene and Carbon Monoxide Chemistry. (1949).

12) H Adkins et al., J. Am. Chem. Soc., 71, 3051 (1949).

13) F. Asinger, Ber., 75, 1247 (1942).

14) L. E. Craig et al, J. Am. Chem. Soc., 72, 3277(1950).

15) A. Willemant, Bull. Soc. Chim., 14, 152 (1947).

16) I. Wender, et al., J. Am. Chem. Soc., 72, 4375, 4842 (1950).

17) Chem. et Eng. News, p. 2446 (1950).

18) G. C. Hall, Chem. Age, p. 115 (1947).

\title{
脂肪族化合物のスルホクロル化
}

Sulfochlorination of Aliphatic Compounds

奥 田 $\quad$ 重 喜*

\section{緒言}

芳香化合物では sulfochloride 基の導入は簡單である が，脂肪族化合物では特別な場合の外は行うことは出來 ない。從來脂肪族の sulfochloride は監化了ルキルに亞 硫酸ソーダ等を反應せしめるか, mercaptan 或は merca-

*要媛大學工學部 ptide 孛酸化して sulfonic acid 或は sulfonate として から五闑化燐を作用せしめ, 或は alkyl magnesium halide に整化スルフリルを作用せしめて作られて來た。

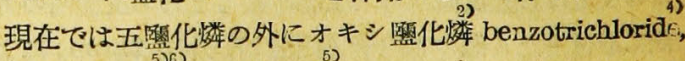

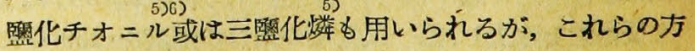
法では sulfonic acid 或は sulfonate は無水物にせねば ならず，少し多量になると非常に面倒でむり，しかるこ れらの方法は一部分解を來たし監化アルキルを件い收量 
る惡く高價なすのになることは既に知られている。

1936 年 Johnson-Sprague 及び Reed が脂肪族 sulfoshloride の調製及び工業的製造法を發表する迄は長い、 間 sulfochlorideは種々の化合物を作る反應性むる中間體 として認められていたがその研究は餘り顧みられなかつ た。スルホンアミド系の醫樂の發達に件い sulfochloride の研究は促進せられ，更に第二次大戰は浸唀濟として高 級脂肪族スルホン酸䜿を要求した。現在高級な alkyl, alizyclic, aralkyl の sulfochloride は浸透劑を第一に,

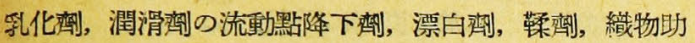
劑，可塑劑，防蝕劑或は合成樹脂等の原料としてその重 要性を益々擴大しつつある。ここではその應用について は割愛することとし, Johnson-Sprague 及び Reed 以來 の脂肪族化合物のスルホクロル化について述べることと する。

現在知られている脂肪族化合物のスルホクロル化ば次 の諸方法に大きく分けることが出來る。

(1) S-Alkylisothiourea (Alkylpseudothiuronium) 監 の水溶液に監素を通じて酸化す (Johnson-Sprague 法)。

(2) 脂肪族の mercaptan, thiocyanate, thiosulfate, disulfide その他の较化物等の水溶液に或は水にサスペン ドして盤素を通じて酸化す，郎ち Johnson-Sprague 法 の擴張。

（3）飽和脂肪族炭化水素中に亞硫酸 ガ スと稳素との 混合ガスを通じて光化學反應による方法 (Reed 反應)。

（4）饱和脂肪族炭化水素をピリジンのような窒素化 合物の存在で留化スルフリルを混じ光化學反碓による方 法 (Kharissh 法)。

\section{Johnson-Sprague}

\section{7)83}

Johnson-Sprague は S-alkylisothiourea 䘧の水溶液 にあるいは水にサスペンドして掵時監素を導入すること により對碓する alkyl sulfochlorideの生ずることを發見 した。もし臭素を用いると sulfobromide を生ずる。當 時はこの方法は注目すべき發見であつた。賽際この方法 はそれ程の設備を要せず，實驗室では葚だ便利で簡單て ある。この一般反應の基礎は1881 年 Rathke がチオ尿 素の構造研究において S-alkyl-N,N'-diphenylthiourea の水溶液に監素及び臭素の作用によりて ethyl sulfonic acidを作つたことからヒントを得て出來上つたるのであ る。その後 55 年間誰もこの反應に注意を拂わなかつた が, Johnson-Spragueはこの一般反應を発見して多數の 脂肪族, 脂肪環狀炭化水素の sulfochloride を良收量で以 て調製した。このようにして簢單にS-methylisothiourea
監から $\mathrm{CH}_{3} \mathrm{SO}_{2} \mathrm{Ol}$ を $70 \%$ の收雍で得た。但しこの方法 は第 1 紘のアルキル基では收量は良好であるが，第 2 湤 のアルキル基では餘り良くなく，第 3 級アルキルでは全 く生成されない。郎ちイソプロビルやイソブチル基のよ うな分技したアルキル基では sulfoshloride の收量は低 い。S-alkylisothioucea 蠕は臭化アルキルとチオ尿素か ら容易に調製されるが，簡單な祭化アルキルは同條件下 ではチォ尿素との反應は非常に遲い。賽際には sulfochloride の調製は S-alkylisothiourea 監の調製の難易にか かつている。臭化アルキルとチオ尿素との反應は殆ど定 量的である。監化アルキルとチォ尿素とではオートクレ

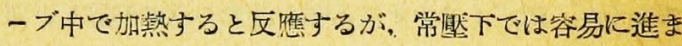
ない。 $\mathrm{C}_{2} \mathrm{H}_{5} \mathrm{Ol}$ 及び isっ $\mathrm{C}_{3} \mathrm{H}_{7} \mathrm{Cl}$ は数闻間チオ尿素々還流 しても對應のS-alkylisothiourea睤に完全に變化しない。 しかし結合しただけのものを絾素比すると $\mathrm{C}_{2} \mathrm{H}_{5} \mathrm{SO}_{2} \mathrm{Cl}$ $66 \%$, is。- $\mathrm{C}_{3} \mathrm{H}_{7} \mathrm{SO}_{2} \mathrm{Cl} 40 \%$ が得られる。便利な方法は Stevens の熨酸盤の調製法である。彼は種々のアルコー

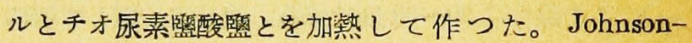
Sprague は高級アルコールにこのう法を應用して成功し

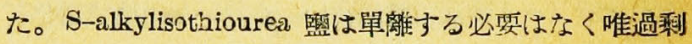
のアルコールを除いて水溶液又は水にサスペンドして陻

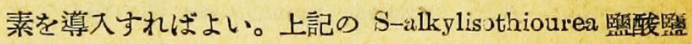
はチォ尿素, 濃盤酸とアルコールとを混合して蒸氣浴上 で 3〜4 日加熱すると最高收量が得られる。エチル，1 ソプロピルやイソプチル化合物の收量の低いのは反應泣 度の低いこと, 郎ちアルコールの沸點, 䜿化アルキルの 揮發性及び分枝鎖の影響等が擧げられる。アルコール， 監酸及びチオ尿素から作る場合には区傄時間の長いこと

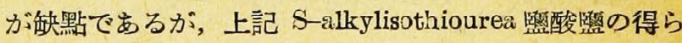

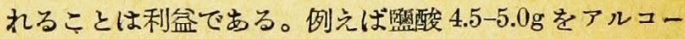
ル 75cc と碎粉したチオ尿素 $7.6 \mathrm{~g}$ を加えて還流冷却器を 付し湯浴上で加熱するとチオ尿素は短時間で溶解する。 アルコールの㣫類によりて反應時間は異なるけれどす正 プロピル, 正ブチルやイソ・アミルアルコールの場合に は 72〜96 時間後には完全にチオ尿奉は消失する。㿼酸 の代りに湓化水素を用いると少し收量はよい。これは sulfochlorideにすると收量が稍良好であることから推論 される。

S-dodecylisothiourea 醖のように高級になるとdodecy1

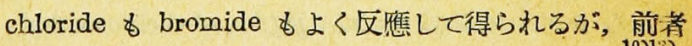
の 4 日間に比し後者は約 10 時間で反應は完全である。 この方法は alkyl halide の外 benzyl や phenylethyl halide のような aralkyl 化合物にも同樣適用することが 出弪亏。又 cyclohexyl, deanhydronaphthalene 誘導遭 
のような alicyclic 化合物にる, 页瞅化パラフィンのよ らな高級なすのに迄應用することが出來る。しかし， cyclohexyl chloride はチオ尿素とは殆ど反雇しない。 その bromide は臭化水素を解倠して溶媒として用いて いろアルコールそ反應してその bromide を作ろ傾向が あるので兩者の混合したイソチオ尿素臭化水素酸湮が出 來る。シクローキサノールはチオ尿素と具化水素酸或は

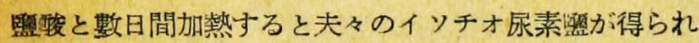
る。 sec.-或は tert.-alkyl chloride 及び bromide も矢 張り解䨆を受けるので Stevens 法によらねばならぬ。

さてイりチオ尿素整の整素酸化に上るスルホクロル化

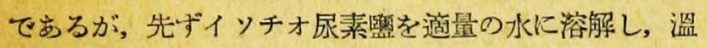
度を $10^{\circ}$ 以上に上げない上らに調節しながら㗍素を通 ず。それ以上の溫度になると sulfochloride が分解して sulfonic acid になる傾向がある。馧素の導入は sulfo-

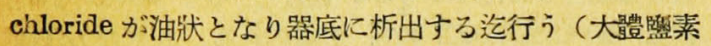
の飽和で終るが油分を分﨎して佾嚳素を通して見るとよ い)。この操作は 20〜30 分で終る。油分は分離して特に 固體のものはエーテルで抽出して過剩の嘕素は $5 \%$ の酸 性亞硫酸ソーダ溶液で數回洗い，水洗いした後で盟化石 灰で乾燥してェーテル除去後減壓蒸溜を行う。

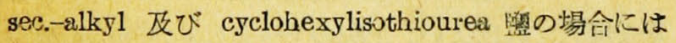
一般に收量は低い。tert.-alkylisothiourea 整の場合には sulfochlor:deは得られず全部が硫酸鶖に酸化される。分 枝 alkyl 基は硫酸整になる傾向が强く sulfochloride の 收量は制限せられる。これら2つの主反應は次のように 表わすことが出來る。

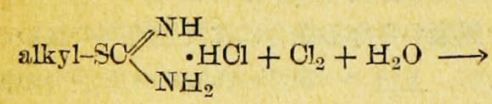

$$
\left\{\begin{array}{l}
\text { I. alkyl- } \mathrm{SO}_{2} \mathrm{Ol}+\mathrm{NH}_{2}-\mathrm{C} / \mathrm{Cl} \\
\text { II. alkyl- }-\mathrm{SO}_{4}+\text { alkylene }+\mathrm{NH}_{2}-\mathrm{C}_{\mathrm{Cl}}^{\mathrm{NH}} \cdot \mathrm{HCl}
\end{array}\right.
$$

Johnson-Sprague は \&-methylisothiourea のメチュ 基の水素原子を種々の基で置換した $\mathrm{R}-\mathrm{CH}_{2}-\mathrm{SC}_{\mathrm{NH}}$ を作りこれを確めた。Ｒは furyl, alcoxy (methoxy, n-butoxy, iso-amyloxy, carboxycarboethoxy) で, suliochloride は得られず何れる硫酸零になる。圆换基 のある $\beta$-chloroethyl acetate 及び $\beta, \beta^{\prime}$-dichloroethyl ether より作られるイソチオ尿素祭からの sulfochloride の收量は侲秀である。純 sulfochloride を得る際に注意

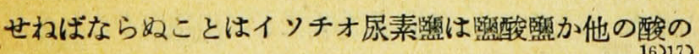

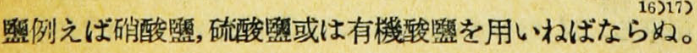

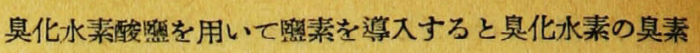
を遊離してこれが反您するために sulfochloride と sulfobromide との混合物が得られる。同樣に sulfobromide

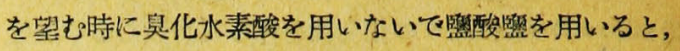
sulfochloride が混じて來る。從て上の理由から sulfoch-

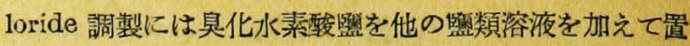
換せねばならぬっこのためには無機酸の整さもよいが有 機酸䜿類を用いろと瞬間に定量的に置換される。特に酢 酸罶のようなるのは都合がよく, 且つ isothiourea acetate 心䁬素酸化に於て圆滑に反應与る。

他のアルキル或は aralkyl-isothiourea 嘕は alkyl 或

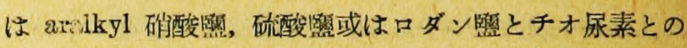
反歪からす出來ろ。例えば硫酸ジェチルからは S-ethylisothiourea saltate が生成される。Folkers 等は formamidinethiol acetic acid hydrochloride, $\mathrm{HOOC}-\mathrm{CH}_{2}-$ $\mathrm{SO}{ }_{\mathrm{NH}_{2}}^{\mathrm{NH}} \cdot \mathrm{HCl}$ 及び $\$$-ethylisothiourea sulfate の場合 に侐素導入中に爆發を起した。これは反應が終つてから 副生された留化空素が爆發の原因であるらしく，反應溶

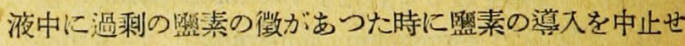
ねばなら双。上記方法による sulfochlorice の調製は米 國以外では殆ど研究されなかつた。

\section{Johnson-Sprague 法の撗張}

S-alkylisothiourea 際の方法は他の硫黄化合物例えば mercaptan, disulfide, thiosulfate, thiolester, thiocarbamic ester, thiocyanate 迄撗張されていつた。これら は何れる水溶液に或は水にサスベンドして監素を導入す ることにより對應する脂肪族 sulfochlorideに變化せし めろことが出來る。これらの硫黄化合物はそれまで芳 香族化合物について研究されたことはあつたが脂肪族化 合物については殆ど行われなかつた。上記硫黃化合物と 整素との操作はイソチオ尿素整に於けると同樣でる。

既述のイソチオ尿素整は荷性ソーダ溶液と妿熱するこ

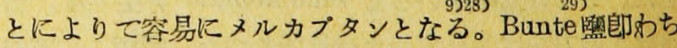
sodium alkyl thiosulfate のアルコール溶液に鈸酸を添 加し還流すると加水分解を受けてメルカプタンとなる。

$$
\mathrm{R}-\mathrm{S}-\mathrm{SO}_{2}-\mathrm{O}-\mathrm{Na}+\mathrm{H}_{2} \mathrm{O} \longrightarrow \mathrm{RSH}+\mathrm{NaHSO}_{4}
$$

この事から溶媒として, 稀醀酸を用いて良收量でして sulfochlorideを作ることが出來る。メルカプタンと有機 酸とのエステル例えば

ethyl thiol acetate, $\mathrm{C}_{2} \mathrm{H}_{5}-\mathrm{SC}-\mathrm{CH}_{3}$

Ö

す国滑に盟素酸化を受けて $71 \%$ の收率で $\mathrm{C}_{2} \mathrm{H}_{5} \mathrm{SO}_{2} \mathrm{OI}$ 
が得られる。

Battegay-Krelos $\mathrm{CONH}_{2}$ を祭集で, S-n-propylthiourethan, $\mathrm{C}_{3} \mathrm{H}_{7}-\mathrm{S}-$ $\mathrm{COVH}_{2}$ を臭素で上記と同栚に處理して $\mathrm{CH}_{3} \mathrm{SO}_{2} \mathrm{Ol}$ 及 で $n-\mathrm{C}_{3} \mathrm{H}_{2} \mathrm{SO}_{2} \mathrm{Ol}$ をそれぞれ殆ど理論的收量で得た。 Johnson-Douglass は脂肪族のロダン祭を支記と同樣に 處理して sulfochlorideの生じることを發先し25)

$\mathrm{R}-\mathrm{SON}+\mathrm{Cl}_{2}+\mathrm{H}_{2} \mathrm{O} \longrightarrow \mathrm{RSO}_{2} \mathrm{Cl}+\mathrm{CNCl}$

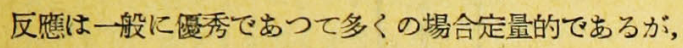
副生される籢化シャンは猛毒な氣體であるから通風下で 注意して行わねばならぬ。

Ziegler-Sprague は alkyl halide とチオ硫酸りーダで alkyl thiosulfate 盟を作り, 既知の方法て種々の stiliochloride を調製した。臭化アルキルとチオ硫酸ソーダと は一般によく反應するが整化アルキルとは反應しない。 ssc,-alkyl bromide は臭化水素が脫出してオレフィンと

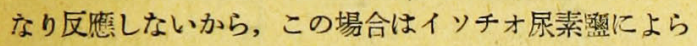
ねばならぬ。alkyl thiosulfate 整は反應によりて生じた

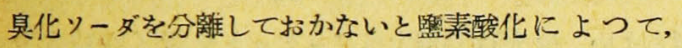
sulfobromide の混じた sulfochloride ‘゙得られる。alkyl thiosulfate 整は少量の りて容易に disulfide, (R-S-S-R) が得られる。これに よろ監素酸化は純粹の sulfochloride が得られる利監が あろ。Hneter は didoderyl disulfide, $\left(\mathrm{C}_{12} \mathrm{H}_{25} \mathrm{~S}\right)_{2}$ を 水にサスペンドして既知のオ法で dodecyl- $\mathrm{SO}_{2} \mathrm{Cl}$ を, Sperling $は$ dicyclohexyl disulfide, $\left(\mathrm{C}_{6} \mathrm{H}_{11}-\mathrm{S}\right)_{2}$ から cyclohexyl- $\mathrm{SO}_{2} \mathrm{Ol}$ を得た。反應型式は次のよ5である。 $\mathrm{C}_{6} \mathrm{H}_{11}-\mathrm{S}-\mathrm{S}_{-} \mathrm{C}_{6} \mathrm{H}_{11}+5 \mathrm{Cl}_{2}+4 \mathrm{H}_{2} \mathrm{O} \rightarrow 2 \mathrm{C}_{6} \mathrm{H}_{11} \mathrm{SO}_{2} \mathrm{Cl}+8 \mathrm{HCl}$

祭酸中でオレフィンと盤化硫黃から作られる chloroalkyl disulfide 例えば $\left(\mathrm{OCH}_{2} \mathrm{OH}_{2}-\mathrm{S}\right)_{2}$ から緗素酸化に よりて 2 モルの $\mathrm{ClCH}_{2} \mathrm{CH}_{2} \mathrm{SO}_{2} \mathrm{Cl}$ が定量的に得られ, $\left(\mathrm{COl}_{3} \mathrm{CH}_{2}-\mathrm{S}\right)_{2}$ 同椂に $\mathrm{CCl}_{3} \mathrm{SO}_{2} \mathrm{Cl}$ となる。又オレフィ

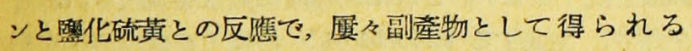
monosulfide 例えば $\left(\mathrm{ClCH}_{2} \mathrm{CH}_{2}\right) \mathrm{S}$ 郎务ちイペリットか らは $\mathrm{ClOH}_{2} \mathrm{CH}_{2} \mathrm{SO}_{2} \mathrm{Cl}$ は1モルしか得られない。 $\alpha$ 位置 整素置換體の sulfide 反應綵慢で收量は甚だ惡い。

Lieber-Cashman は最近炭素原子 8 以上のパラフィン 蟃の䜿化物をチオ尿素で處理して既知の方法で, sulfochloride の製法を發表した。

\section{Reed 反應}

Cortes L. Reed は 1936 年 6 月石油系の液狀飽和炭 化水素を光線に照射の下で祭素と亞就酸ガスの混合物で 處理して重合を避けるために溫度を適當に低溫度に調節
ナることによりて suliochloride の得られること發表 した。次でェタンプロパンのようなガス状炭化水素を あ同樣に處理して $\mathrm{C}_{2} \mathrm{H}_{5} \mathrm{SO}_{2} \mathrm{Cl}, \mathrm{C}_{3} \mathrm{H}_{7} \mathrm{SO}_{2} \mathrm{Cl}$ を作つた。 その反隹型式は次のようである。

$$
\mathrm{RH}+\mathrm{SO}_{2}+\mathrm{Cl}_{2} \stackrel{\text { 光粭 }}{\longrightarrow} \mathrm{RSO} \mathrm{Ol}_{2}+\mathrm{HOl}
$$

更に很は反䣸物の精製法をも發表した。續い・芳香族及 び不饱和化合物を含まない $300 〜 390^{\circ}$ 溜分の炭化水素に 應用してこれより浸唀劑に適するものを得た。

Reed の發見した方法はその原料が炭化水美，䈘，硫 黄空氣と光であるので重要であつてこれらの原料は容易 に得られ，比較的安價でむり，しかも谷易に suliochloride が得られる。それ以來多方面に價値が見出され，そ の研究も時と共に增加し, 多數の特許に現われ, その多 數の誘導體は急速に有盆な分野を開拓しつなむる。この スルホクロル化法を Reed 反譍と呼んでいる。この反 否は實際にはメタンから始つてオクタデカンのような固 體に至る迄, 更に alieyclic, ar lkyl 及び aromatic 伦 合物に迄應用の出來る特筆すべき反仵である。

反應の機構については未だ確定されていない。Reed は中間體として chlorosulfinic ester, $\mathrm{RR}^{\circ} \mathrm{CHO} O-5 \mathrm{C}_{\mathrm{Cl}}^{\mathrm{O}}$ を 提案したが疑問である。亞硫酸ガスと瞖素との反恩は盟 化スルフリルになることは既知のことで, 整化スルフリ ルは一般に鴯素化劑として用いられるすのである。Reed 反㷳は硫黄化合物の生成である。實際には多くの場合反 㟲はスルホクロル化が主反應で炭化水素の笽素化も起る

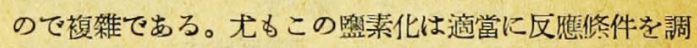
節することによりて抑制することが出柬る。Reed はこ

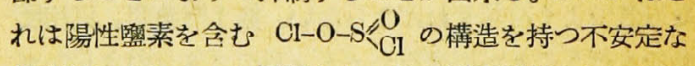
巽性型によるものと解釋した。他の反應機構としては憵 素化中に生成されると信じられる遊離ラジカルが $\mathrm{SO}_{2}$ に附加して他の型の遊離ラジカルを生成し，これが暨素 分子と反應して alkyl sulfochloride となる。

$$
\begin{aligned}
& \mathrm{R}^{-}+\mathrm{SO}_{2} \longrightarrow \mathrm{RSO}_{2}^{-} \\
& \mathrm{RSO}_{2}^{-}+\mathrm{Cl}_{2} \longrightarrow \mathrm{RSO}_{2} \mathrm{Cl}+\mathrm{Cl}^{-}
\end{aligned}
$$

4Is)

Stauff はスルホクロル化の反應速度は炭化水素の濃度 と同波長の吸收されろ光の强さに比例することを示し た。しかし一般に Reed 成應は Asinger (後述) が明ら かにしたように多少の alkyl chlorideを件つてスルホ》 ロル化された異性體の混合物を生ずる。

Reed 反應の實際的發達は偶然にも米國と獨逸て夫々 獨立して行かれて來た。戰爭は本發達を刺战した。それ は喠々の工業に供給する楽品を作る中間體であつたから 
でもる。最も重要なのは，嘗時は長鎖の飽和炭化水素の suliochlo-ideを荷性ソーダで羭化して得られる表面活性 劑であつた。獨逸の元 I. G. 染料會社は 1939〜 40 年頃 から管施した。I. G. 什は Fischer-Tropsch 生產物の溜 分 Kogasin II (bp 230 320 ) を水素源加して本均炭 素箕 15 の Mepasin なるものを得て, これをスルホク ロル化した。 Mersol D といらのは monosulfochloride $50 \%$, disulfochloride $30 \%$ ，未反應物 $20 \%$ を含むるの で, Mersol H は monosulfochloride $50 \%$, 未反應物 50\%を含むりのであつた。末反應物の分離は容易でなく disulfochloride を合んでいたので, その羭化物 Mersolate は浸透劑として優秀ではなかつたが特別の工業目的には 石羷より倷秀であつた。E. I. du pont 社では Reed 反 應により得たスルホン酸盟は MP-189 なる商品名で販 賣された。酸,アルカリの何れにす非常に安定でカルシ ユームにも完全に抵抗力がありしかも安價で多方面の 應用に有効で，現在では重要な浸透劑の一群に虽し益々

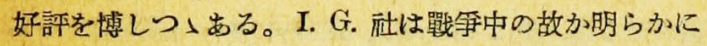
米國の特許に現われた技術を模做し根本的改良には殆ど 主献しなかつた。

Reed 反應は光線を照射しながら低溫度に保つた饱和 炭化水素に亞硫酸ガスと暳溸との混合ガスを導入するこ とによりて簡單に行われる。操作に關する詳細は多数の 特什及び綜說に現われている。賽驗室で行うにはパイレ ックスガラス圆筒に炭化水素滴下漏斗，ガスの導入及び 排出管, 鹠䢁器及び冷却裝置を取付け光線を照射しなが ら炭化水素が反應によりその豫定量になる迄亞硫酸ガス

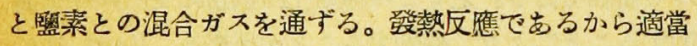
な方法でよく冷却せねばならない。第 1 圖參照。氣相反 隹でも行うことが出來るがメタン乃至ブタンのようなガ ス狀のものは有機溶媒を用いる。それには亞硫酸ガス及

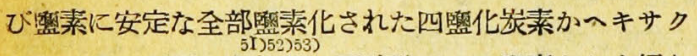
ロロエタンが用いられる。亞硫酸ガスは監素よりも絕え

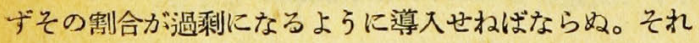
は炭化水素の䉭素化を減ずると共に光線下では炭化水素

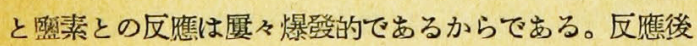
は溶媒を除去して sulfochloride は自空蒸溜して得られ ろ。残渣は主として disultochloride である。これは再 結晶によりて精製することが出來る。

Pilot plant による製法は筫驗室法と大差なく，これ を擴大して器材を考慮すればよい。反應器は不錆鋼, 鐵, アルミニウム，銅或いは銅合金は何れる滿足でない。䗟

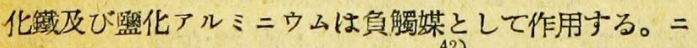
ッケル, ニッケル非鐵合金は苏足で, エナメル引きす磁

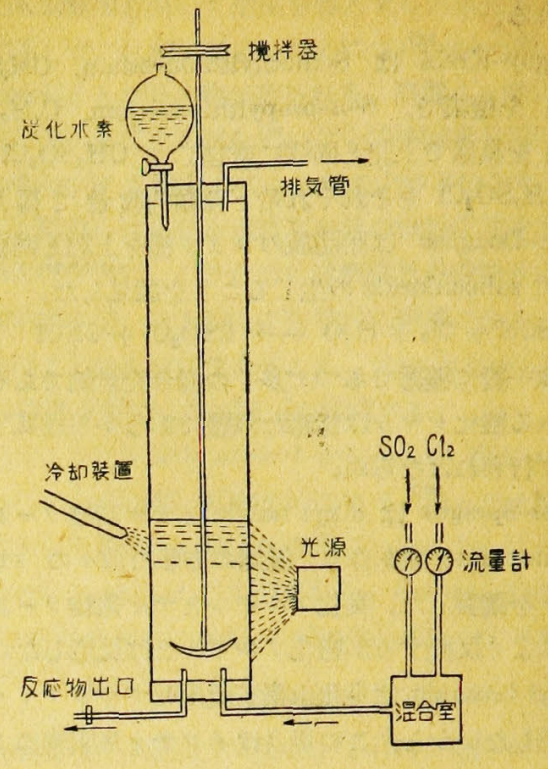

第 1 團

製るよい。冷 却は容器上にジャケットを置くか或は內 部に冷却器を入れる。光線は反應器內に光線管を入れる か或は反碓器の外側に透過空を作つてもよい。I. G. 社 の反碓器は石炭酸樹脂で塗裝した銅製であつた。これは

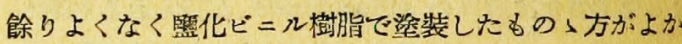
つたといわれる。

優秀な浸透劑としてその他の原料として保證するため には反應物は精製せねばならない。スルホクロル化は普 通 $50 \%$ 以下の反焳で中止せられるので末反應の炭化水 素を除去せねばならぬ。そのためには普通選擇溶劑を用 いる。液化無水亞硫酸, (bp $\left.-10^{\circ}\right)$ は sulfochloride を溶 解するが未反應の炭化水素は溶解しない。完全な分離に は更にン゚ンタン或はへキサンのよらな低沸溶劑で無水亞 硫酸を洗うとよい。これは反應液に無水亞硫酸を入れ層 を作り，生成する sulfochloride の無水亞硫酸溶夜を引 拔き，上首の未反應炭化水素を反碓器に歸すよ5に連續 的に行うことが出來る。この方法は monosulfochloride が生成されるとすぐに反應圈外に出されるので polysulfochloride の生成が少ない。無水亞硫酸の外にメタ〉 ル, キ酸メチル,プロピオニトリル或いはニトロメタン のよ5な溶劑も分離には有效でむる。高紣脂肪族炭化水 素の polysulfochloride から monosulfochloride の分離 は稍困難で未反㷳の炭化水素を除去してからペンタン中 に反應物を大れ $-35^{\circ}$ に冷却すると di- 及び polysulfochloride はこの溫度ではン゚ンタンに不溶である。 
Reod 反應に應用出來る炭化水素としては多數の特許 ガある。短鎖ガス狀パラフィン゙, 長鎖パラフィン，分枝 鎖パラフ 1 亿, 脂肪環㭊化合物, アルキル鎖を持つ脂肪 環狀化合物，長鎮アルキルベンゼン，監化パラフィン， テルペン炭化水素, セテンのようなオレフィシ，5炭素 原子以下のオレフィン重合體等であつて, 塺力下では脂 肪族反び脂肪環狀化合物のモノカルボン酸も或條件下C は反應する。或種の長鎖化合物も固換基が長鎖の影绵の 少い場合には反應を受ける。これら化合物はアルコール 酸、ハライド, ニトリル等子含まれる。

I. G. 社の.Asinger 等は低級な炭化水素について詳細 に研究を行つた。四監化炭素にプロパンを溶解し紫外線 照射の下に亞硫酸ガスと恤素との混合割合を $2.5: 1.1: 1$ で反應せしめ $\mathrm{C}_{3} \mathrm{H}_{7} \mathrm{SO}_{2} \mathrm{Ol}, \mathrm{ClC}_{3} \mathrm{H}_{6} \mathrm{SO}_{2} \mathrm{Cl}, \mathrm{Ol}_{2} \mathrm{O}_{3} \mathrm{H}_{5} \mathrm{SO}_{2} \mathrm{Ol}$

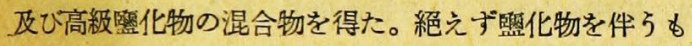
のであつて, 主溜分 $70 \sim 90 \% / 15 \mathrm{~mm}$ のものを再溜して $\mathrm{OH}_{3} \mathrm{OH}_{2} \mathrm{CH}_{2} \mathrm{SO}_{2} \mathrm{Cl}$ と $\mathrm{CH}_{3} \mathrm{CH}_{2} \mathrm{CH}\left(\mathrm{SO}_{2} \mathrm{Cl}\right) \mathrm{CH}_{3}$ が $1: 1$ の割合にあることを證した。残椬は $\mathrm{OlC}_{3} \mathrm{H}_{6} \mathrm{SO}_{2} \mathrm{Ol}$ の 3 翼性體の混合物であつて分溜は出來ない。disulfochloride は $\mathrm{CH}_{2}\left(\mathrm{SO}_{2} \mathrm{Cl}\right) \mathrm{CH}_{2} \mathrm{CH}_{2}\left(\mathrm{SO}_{2} \mathrm{Cl}\right)$ であつて m. $48^{\circ}$ であつた。

ブタンの場合も前者と同樣の割合で四盤化炭菜中で行 つて $\mathrm{C}_{4} \mathrm{H}_{9} \mathrm{SO}_{2} \mathrm{Ol}, \mathrm{C}_{4} \mathrm{H}_{8}\left(\mathrm{SO}_{2} \mathrm{Cl}\right)_{2}, \mathrm{ClO}_{4} \mathrm{H}_{8} \mathrm{SO}_{2} \mathrm{Ol}$ を 85 : 10〜11:3〜 5 の割合で得てその物理恒數を明らかにし t。 $\mathrm{CH}_{2}\left(\mathrm{SO}_{2} \mathrm{Ol}\right) \mathrm{CH}_{2} \mathrm{CH}_{2} \mathrm{CH}_{3}, \mathrm{~b}_{15} 93.5^{\circ}, \mathrm{OH}_{3} \mathrm{CH}\left(\mathrm{SO}_{2}\right.$ Cl) $\mathrm{CH}_{2} \mathrm{CH}_{3}, \mathrm{~b}_{15} 85^{\circ} . \mathrm{CH}_{2}\left(\mathrm{SO}_{2} \mathrm{Cl}\right) \mathrm{CH}_{2} \mathrm{CH}_{2} \mathrm{CH}_{2}\left(\mathrm{SO}_{2} \mathrm{Cl}\right)$, m. $83.5^{\circ}, \mathrm{CH}_{2}\left(\mathrm{SO}_{2} \mathrm{Cl}\right) \mathrm{CH}_{2} \mathrm{CH}\left(\mathrm{SO}_{2} \mathrm{Cl}\right) \mathrm{CH}_{3}, \mathrm{~m} .41 .0^{\circ}$ あつた。

イソブタンの場合も同様にして $\left(\mathrm{CH}_{3}\right)_{2} \mathrm{CHCH}_{2} \mathrm{SO}_{2} \mathrm{Cl}$, $b_{15} 87^{\circ}$ が $75 \%$ 以上得られた。殘渣は璺素化された monosulfochloride と $1 \%$ disulfochloride, m. $188^{\circ}$ 厄 むる。同研究に於て thiocyanate 法により iso- $\mathrm{O}_{4} \mathrm{H}_{9} \mathrm{SO}_{2} \mathrm{OI}$ を $91 \%$ の收量で得ていることは注目すべきである。 tert. $\mathrm{C}_{4} \mathrm{H}_{9} \mathrm{SO}_{2} \mathrm{Cl}, \mathrm{b}_{15} 80$, は thiocyanate 法o isothiourea 法す出來ないが $\left(\mathrm{OH}_{3}\right)_{3} \mathrm{C}-\mathrm{SO}_{3} \mathrm{H}$ のナトリウム監に

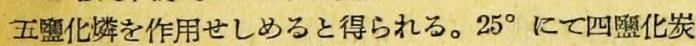
素中てプロパン及びプタンのスルホゥロル化は同條件下 にて或は過剩の炭化水素を存在すれば $300^{\circ}$ にて氣相に 於ける直接整素化と同樣な關係がある。例えば $30^{\circ}$ で四

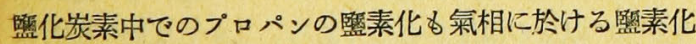
๒共に 1 及び 2 置換體の割合は夫々凡そ 48 更び $52 \%$ であるが，250で四監化炭素中でのスルホクロル化は夫 々の置換體は共に $50 \%$ でもる。ヌブタンの氣相監素化

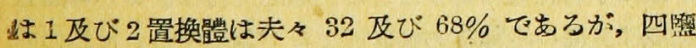

化炭素中でのスルホクロル化では夫々置換體は 33 反び $67 \%$ むる。イソブタンの氣相際素化では 1 及び 2 置換 體は 37 及び $33 \%$ であるが, 四函化炭素中でスルホクロ ル化では $25^{\circ}$ で1置換體のみ $100 \%$ を生ずる。第3 級の 水素原子は䤈素にて置換されるが $\mathrm{SO}_{2} \mathrm{Cl}$ 基によりては 置換されない。gem-及び $\alpha, \beta$ 位置の兩置換は見られな い故にスルホクロル化のよくないのはこのためである。

ドデガン, $\mathrm{O}_{12} \mathrm{H}_{26}\left(\mathrm{~b}_{758} 216 \sim 8^{\circ}, \mathrm{m} .-15^{\circ}\right)$ の場合も同 樣に處理して sulfochloride を無水亞硫酸或は propionitrile で抽出し或は約 $90^{\circ}$ で㐮空で過熱蒸氣を通じて分 離した。その際 sulfochlorideは殆ど分解しない。di-及 び polysulfochlorideはペンタン沈澱せしめた。之等は低 溫でヘンタンに不溶である。 monosulfochloride の混合 物はキシレンで還流すると $\mathrm{SO}_{2}$ が焀却されて元 $\mathrm{SO}_{2} \mathrm{OI}$ 基により占められていた位置に $\mathrm{Ol}$ のある陵化ドデシル （收量 $80 \%$ ）の混合物を生ずる。このようにして $\mathrm{SO}_{2} \mathrm{OI}$ 基の入ろ位置は一定しないことを次のようにして證明し た。僰华ドデシルは二重結合の移動を防ぐためにステフ リン酸銀で脫夓酸により生ずるオレフィンを酸化銀で酸 化してカルボン酸としてその分溜によりて $\mathrm{C}_{6}$ から $\mathbf{C}_{11}$ 迄の酸の割合を調查した。これは Hass 等の炭化水素の

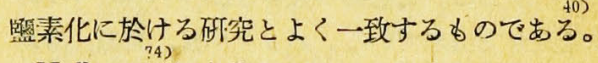

Helberger によるとシクロへキサンのスルホクロル化 は $\mathrm{C}_{6} \mathrm{H}_{11} \mathrm{SO}_{2} \mathrm{Ol}$ と trans-1, 4-cyclohexyldisulfochloride を生ずる。兩者共に容易に $\mathrm{SO}_{2}$ を失つて對應する核盤化 物を生ずろ。文短鎖の 1-chloroparaffin は $\mathrm{SO}_{2} \mathrm{Ol}$ 基と 作用して sulfone を生ずる。区應は次式のように起り 60 \%の收率で sultone を生ずると斷定している。1-chlorobutane を例に取ると

$$
\begin{gathered}
\mathrm{CH}_{3} \mathrm{CH}-\mathrm{CH}_{2} \mathrm{CH}_{2} \mathrm{Ol} \longrightarrow \underset{\mathrm{S}_{2} \mathrm{Cl}}{\longrightarrow} \underset{\mathrm{CH}_{3} \mathrm{CH}-\mathrm{CH}_{2} \mathrm{OH}_{2} \mathrm{Cl}}{\mathrm{SO}_{2} \mathrm{OH}} \\
\longrightarrow \underset{3}{\mathrm{CH}_{3} \mathrm{OH}-\mathrm{CH}_{2}-\mathrm{CH}_{2}} \\
\mathrm{SO}_{2}-\mathrm{O}-\mid
\end{gathered}
$$

この反應に於て $\mathrm{SO}_{2} \mathrm{Ol}$ 基は血素原子から最も隔つた 第 2 級或は第 3 級の炭素原子に大り,この sultone は種 々の化合物例えば $\mathrm{KI}, \mathrm{KCN}, \mathrm{KSCN}$ 等と $\omega$ 置換のス ルホン酸㿼を生ずる。例えば

$$
\underset{\mathrm{SO}_{2}-\mathrm{O}-\mathrm{CH}}{\mathrm{CH}_{3}-\mathrm{CH}-\mathrm{CH}_{2}-\mathrm{OH}_{2}}+\underset{\mathrm{KON}}{\rightarrow} \underset{\mathrm{OH}_{3}-\mathrm{CH}-\mathrm{CH}_{2}-\mathrm{CH}_{2} \mathrm{ON}}{\mathrm{SO}_{3} \mathrm{~K}}
$$

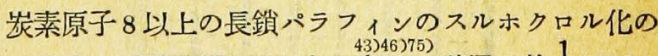
ポリ置換は反應の進むにつれて起る。普通は約 $\frac{1}{2}$ 以下の sulfochlorideの生じた時に混合ガスの導入を中止する。 最初の炭化水素量の 10２0\% がスルホクロル化され た時には約 $90 \%$ が monosulfoshloride で $10 \%$ が 
đ゙ sulfochloride として存在す。50\% 變化した時には約 7(1\%が monosulfochloride で，70\% 變化した時には約 同量の mono- 及び disulfochloride が含まれる。

又 Helberger 等は chloroparaffin に $500 W$ ランプ で㚙射して亞硫酸ガスと雨素を 1.5〜3.0:1 の割合で20 時間通じて祭素が理論上 $50 \%$ 吸收した時に反應を中止 して生成物を檢した。 $\mathrm{CH}_{2} \mathrm{ClOH}_{2} \mathrm{CH}_{3}$ は $\mathrm{CH}_{2} \mathrm{ClCH}\left(\mathrm{SO}_{2}\right.$ O1) $\mathrm{CH}_{3}$ が主成分で僅かに 1,3-置換體を伴つた。 $\mathrm{CH}_{3}$ $\mathrm{C}-\mathrm{ClCH}_{3}$ は $\mathrm{CH}_{2}\left(\mathrm{SO}_{2} \mathrm{Ol}\right) \mathrm{OHClOH}_{3}$ を, $\mathrm{CH}_{2} \mathrm{ClCH}_{2}$ $\mathrm{CH}_{2} \mathrm{CH}_{2} \mathrm{OH}_{3}$ は inonosulfochloride の混合物 $60 \%$ と dichlorobutane $20 \%$ を得, 前者はその内 2-置換體 $39 \%$, 3-置换體 $49 \%$ 及び 4-置换體 10\% であつた。

Detrick 等は液狀鴒和脂肪族の polysulfochloride の逨 續的製造法を明らかにした。第 2 3 圖に示すような型 の器で行うことが出來る。第 3 浻は第 2 圖の一部を示す りので反應器は下方に水平に磁製の有孔板の仕切りによ りて2 部分に壮切られ, 中央に $3000 \sim 4000 \AA$ の光を出 寸篮光燈を入れた光源とランブを取卷く冷却器がある。

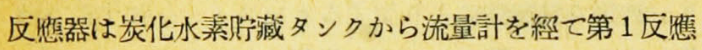
器に入り, 第 7 反應器より流出する。各反應器には過剩 ガスの排出口がある。反䈍器の大いさは $66^{\prime \prime} \times 33^{\prime \prime} \times 12^{\prime \prime}$ セ內部は站張りで出來ている。バッフル板, 光源, 冷却 器は何れす碀硅素ガラスより成る。操作は液狀鴒和炭化 水素例えば bp 263 305 のすのを $58 \mathrm{lb} / \mathrm{hr}$ の速さで第 1反應器の內部に連緹的に入り,ンシッフル板を經て順次 各部反應器を通つて第 7 反痽器の下部より出る。最初同 時に $\mathrm{SO}_{2} 14.5 \mathrm{lb} / \mathrm{hr}$ と $\mathrm{Cl}_{2} 12 \mathrm{lb} / \mathrm{hr}$ の混合物を下部の有 孔板を通つて連績的に導く。過剩のガスは排出口より出 ろ。反應物は冷却器により 25〜30 に保たれる。溢流す る反倠物は sulfochloride と末反應の炭化水素より成り, 比重 $\left(30^{\circ}\right)$ は 0.940 て $77 \mathrm{lb} / \mathrm{hr}$ の速さで生產される。

最近の興味のあるのは Rust 等は $\mathrm{O}_{\mathrm{n}} \mathrm{H}_{\mathrm{an}_{\mathrm{n}}+1}-\mathrm{O}-\mathrm{O}-\mathrm{O}_{a}$ $\mathrm{H}_{\mathrm{q}_{\mathrm{n}+1}}$ 型の di-tert.-alkyl peroxide 老光線下て亞硫酸

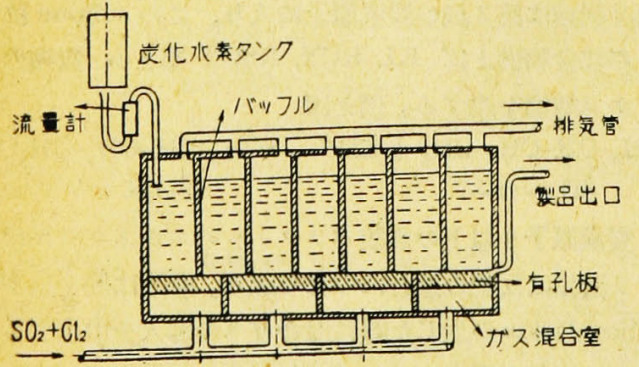

第 2 團

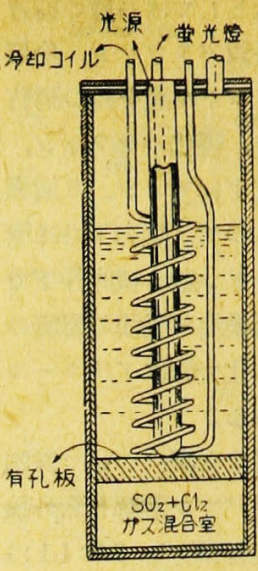

第 $\mathbf{3}$ 、團

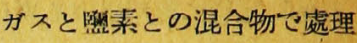
して安定な sulfochloride を 作つた。例えば di-tert-iuty1peroxide からは 2-tert-butylperoxy-2-methylsulfochloride, $b_{1} 72 \sim 77^{\circ}$ が得られる。<smiles>COC(C)(C)OOC(C)(C)OOC(C)(C)OC</smiles>

これから得られる遊離酸は他 の有機過酸化物のよ5に重合 反倠の促蕉劑として用いられ ろ。貯藏中も㣫㢣により爆發せず，普通のスルホン酸の 溶解性を持つている。

Reed 反應を行うに當つて反應に影響を與える多敷の 因子がある。亞硫酸ガスと祭素との混合割合, 反應溫度, 反倠の中止點, 原料の純度, 光線の種類と波長, 他の触 媒の存在等が學げられる。反應物の成分からして Reed

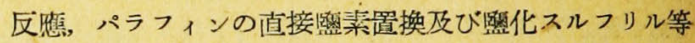
の生成が可能である。稳化スルフリルの生成は多數の化 合物によりて促進せられる。整化スルフリルは倐件次第 によりて監素化劑となり，又スルホン化劑ともなる。從 つて反應に與かる炭化水素は充分に精製したすのを使用 せねばなら外石油溜分を用いる時には硫酸, 發䣲硫酸 或は燐酸で次にアルカリで處理して, 冷却して, 固形分を 除いて分溜するか或は吸着劑で處理して精製しなければ なら奴。不脃和化合物や芳香族結合の二重結合が存在す ると Reed 反應の初まる前に整素置換反應が起り Reed 反隹を防害する。又酸素含有化合物るよくない。若干の 㨘素置換は避けられないからこれを最小にするために

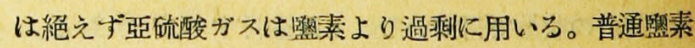
1 モルに對して亞硫酸ガスは $2.5 \sim 3.5$ モルがよい。

反碓溫度はパラフィンの種類によりて變えねばなら 如。普通の液狀パラフィンは常溫で行う。液體無水亞硫 酸及び液體㫼素とパラフィンを混し゚てー20〜-100 で行5 ことも出來ろ。このような低溫で行らことす出來るが餘 り低溫では反伤速度が荤い。パラフィン蝈はその融點よ り $5-10^{\circ}$ 以上の溫度が必努である。しかし反應が進むに つれて或範園溫度を下げることが出來る。混合ガスは氣 泡の小さい程有効であるから强力な撜拌器を取り付ける か或は小有孔板のようなるのを通して行う。ガスの通過 速度は設㣁の椧却能力如何によりて調節する。反應の中 
此點は生成物の希望に應じて预め實驗によりて比重を決 定しておかねばならぬ。

Reed 反碓は光化學的であるから光線の波長が最も大 场なある。光線はどんな種類のものでるよく日光, 紫外

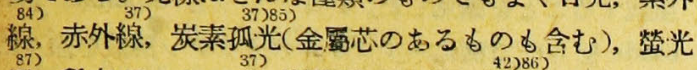
燈, 稀有ガスランプ, 寫值用の漼光ランプ, 普通の透明

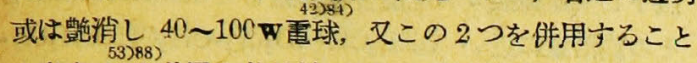
も出來るが, 普通は紫外線が用いられる。波長は 3300〜 $5000 \AA$ のスベクトルの範園で最も满足であつて勿論パ イレックスガラスを透過する。6000̊ 以上の波長は無効

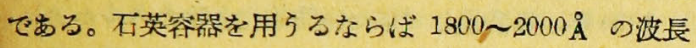
でる有効である。短㳊長は石英壁上に炭化水素が焦げつ く。光線を用いない場合は䜿素置換反應のみ起つてReed 反應は進まない。しかし後述する特殊の觸媒が發見され てReod 反㮣に用いることが出來るようになつて來た。

Reed 反應に於て光綜を照射しながら亞砥酸ガスと晒 素との混合物で反應せしめる際にピリジン,ピペリジン, キノりン等のような窒类化合物を使用することが出來 る。.I. G. 唒は 1914 年脂肪族化合物のスルホクロル化 は trimeric actone peroxide, dihydropropyl peroxide の $0.03 \%$ 存在すれば滑面の鐵より粗面の鐵反應器で有 効であり，舀素置換體を著しく減少せしことことを報告 した。又㷰化第二錫, 五整化燐, 硫黄或は驖を芑める硅

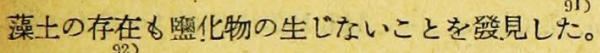

Detrick 等は臷の有害作用は少量の燐酸エステル例え ば Lorol phosphate (10 18 炭素原子のアルコールの mono 及び diphosphate の混合物)を原料パラフィンに 添加して反應せしめることによつて克服した。

Reed 反應を光線の照射なしに有機䒈媒を用いてて行う 方法が米國と獨逸で各々獨立して發見せられた。今命盛 んに研究されている。ピリジンの上うな窒素化合物或は dibenzyl peroxide を加えて㹂找しながら亞硫酸ガスと 艋素との混合ガスを通ず。 lauroyl peroxide, phthaloyl peraxide のようなるのるよい。その添加量は mono 或 は polysulfochloride を作るかによつて加減する。四エ チル鉆, 四エチル錫,トリフェニル蒼鉛,ヂメチルカドミ ニームのような有機金層化合物, t:iphenylmethyl, benzoyl pəroxide, azomethane, azopropane 及び assiridole 等も提案された。

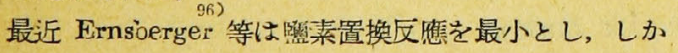
る光線を使用せずに常法により脂肪族アゾ化合物例えば $a, a^{\prime}$-arobis(isobutyronitrile) を用いることによりスル ホクロル化を有効ならしめる觸媒を特許とした。

Reed 反䣸を工業的に行う場合には排ガスの回收が必

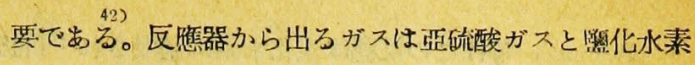
と少量の留素である。それ故にこれらのガスを回收し或 いは利用を㘣らねばならぬ。この混合ガスは更に盤素と 混合して木炭或は他の適當な觸媒上を通して整化スルフ

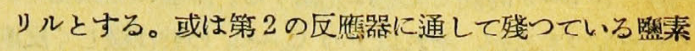
を利用して反應せしめて亞硫酸ガスは冷却して回收し再 び利用する。際化水素は更に精製して他の目的に使用せ られる。

\section{Kharasch 法}

Reed 区碓は亞硫酸ガスと㱷素との混合ガスの代りに 慗化スルフリルで代用することが出來る。この場合る光 線は必要であるが，最近 Reed 反應と同樣に光線を用い、 ないで有機觸媒を用いるす法が發見された。Kharasch とその協力者は脂肪族炭化水素を光線を照射しつャピリ ジン或はキノリンのよ5な窒素化合物の存在で䣄化スル フリルを用いて sulfochloride の生成されることを篮見 した。監化スルフリルはイオン化觸媒例えば炭素の存在 で $300^{\circ}$ でメタンを隟素化することは以前から知られて いる。この條件下では整化スルフリルは完全に $\mathrm{SO}_{2}$ と $\mathrm{Cl}_{2}$ に解離せねねばならぬ。炭化水采の盟素置換は恐らく 遊離隤素の存在するためらしい。これに反してKharassh 等は極少量の過酸化物の存在では奟肪族炭化水素は低溫 でも盟媇置換の起ることを發見した。恐らく際化スルフ リルの光線による分解ではないらしい。觸媒がなければ 光線を當てつも反應は非常に綏慢であるからである。之

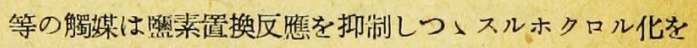
促淮せしめるのに最も有効である。

$\mathrm{RR}^{\prime} \mathrm{CH}_{2}+\mathrm{SO}_{2} \mathrm{Cl}_{2} \longrightarrow \mathrm{RR} / \mathrm{CH} \cdot 5 \mathrm{O}_{2} \mathrm{Cl}+\mathrm{HCl}$ 反應は恐らく遊晟ラヂカル機構で進むらしくこれは昌 肪族化合物や芳香族化合物核につい脂肪族側鎖に比校 的容易に反應することから說明することが出來る。最る 都合のよい條件は强い光線の照射と低濃度の酰化スルフ リルを必要とする。この方法の利谷とする所はReed 区 應のように混合ガスを通すことなく只反應混合物を光線 照射下で還流するだけである。例えば正へプタンにキ， リンを觸媒として反應溫度を 60 〜 $70^{\circ}$ に保ち $31 \%$ の收 率でその sulfochlorideを得た。シクロへキサンに mercaptothiazoline を觸媒として用いてタングステンラン

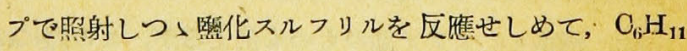
$\mathrm{SO}_{2} \mathrm{Cl}$ と $\mathrm{C}_{6} \mathrm{H}_{11} \mathrm{Cl}$ を得, 七テンのような高級なるのる ピリジン,キノリン, triphengl phosphine,むるいは,

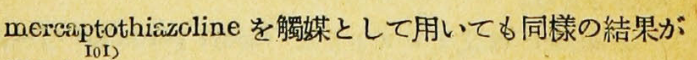
得られる。 
Kharasch 等はこの反應は炭化水素に制限されず脂肪 族カルボン酸及びその無水物にす適用出來ることを發見 した。一般に 200〜300Wの普通の白熱登を用いて 50〜 $60^{\circ}$ で 3〜4 時問で應は完結寸る。酶酸は盕素化され るのみであるが，それ以上の $\mathrm{O}_{3} \sim \mathrm{O}_{6}$ の酸は激しく反應 して sulfochloride とはならないて環狀の $\beta$ 或は $\beta$ と の sulfocarboxylic anhydride が生成ざれ, 同時に極微 量の $\alpha$ 位置の監化物を生ずる。例えばプロピオン酸と祭 化スルフリルでは

$$
\begin{gathered}
\mathrm{CH}_{3} \mathrm{CH}_{2} \mathrm{COOH}+\mathrm{SO}_{2} \mathrm{Cl}_{2} \longrightarrow \stackrel{\mathrm{CH}_{2}-\mathrm{COOH}}{\mathrm{CH}_{2}-\mathrm{SO}_{2} \mathrm{Ol}}+\mathrm{HOl} \\
\underset{\mathrm{CH}_{2}-\mathrm{SO}_{2} \mathrm{Cl}}{\mathrm{CH}_{2}-\mathrm{COOH}} \rightarrow \stackrel{\mathrm{OH}_{2}-\mathrm{CO}}{\mathrm{CH}_{2}-\mathrm{SO}_{2}}>\mathrm{O}+\mathrm{HCl}
\end{gathered}
$$

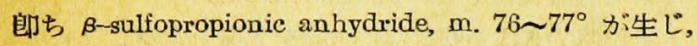
充分に乾燥してなければ $\beta$-sulfopropionic acid, m.102 $103^{\circ}$ が生ずる。又 isobutyric acid では $\beta$-sulfobutyric acid, $b_{3-5} 135 \sim 145^{\circ}$ が $46 \%$ と $\alpha$-chloroisobutyric scid が $28 \%$ 得られる。

盕化スルフリルによるスルホクロル化の場合に觸媒と

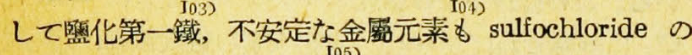
收量を增大せしめる。Ross 等は少くとも炭素原子 6 以 上の饱和炭化水素と䑁化スルフリルから sulfochlorid $\theta$

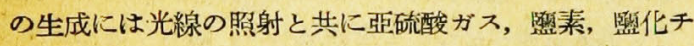
オニル或は一酸化炭素のような無機觸媒の有効なことを 發見した。例えば Pennsylvania 系ガス油 (bp 254〜 $315^{\circ}$ ) 中に祭素を通じ反慜器の內部をタングステンラン

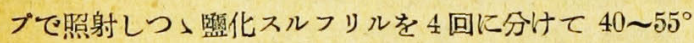

\begin{tabular}{|c|c|c|c|c|c|}
\hline 艦 & 媒 & 照 & \multicolumn{2}{|c|}{ 射 } & $\begin{array}{l}\text { ス木 } \\
\text { 口几化 } \%\end{array}$ \\
\hline \multicolumn{2}{|c|}{ 照 } & \multicolumn{3}{|c|}{ 無 } & 0 \\
\hline \multicolumn{2}{|c|}{ 無 } & $250 \mathrm{~W}$ 水 & 銀. & 燈 & 0 \\
\hline 糆 & 素 & \multicolumn{3}{|c|}{ 無 } & 0 \\
\hline 璺 & 素 & \multicolumn{3}{|c|}{ 40W タングステン憕 } & 33 \\
\hline 璺 & 素 & $250 \mathrm{w}$ 水 & 銀 & 燈 & 64 \\
\hline \multicolumn{2}{|c|}{ 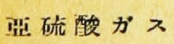 } & $250 \mathrm{w}$ 水 & 銀 & 燈 & 41 \\
\hline \multicolumn{2}{|c|}{ 一酸化炭素 } & $250 \mathrm{~W}$ 水 & 錄 & 燈 & 42 \\
\hline 硫 & 黃 & $250 \mathrm{~W}$ 水 & 銀 & 器 & 25 \\
\hline \multicolumn{2}{|c|}{ 盟化チオニル } & $250 \mathrm{~W}$ 水 & 銀 & 燈 & 65 \\
\hline
\end{tabular}
で反應せしめる。へプタデカンでは次の結果が得られた。

尙，觸媒としてアゾ型のすのす使えるが，この際には

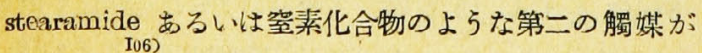
必要である。

Kharasch は丈オレフィンと diacyl peroxide (1〜2 mol\%) の混合物を $60 \sim 70^{\circ}$ に保ち,オレフィンに篮化
スルフリルを溶解したすのを滴下すると dichloro誘導體: の外に登化スルフリル1モルに對してオレフィン 2 モル に相當するすのを含む多量の化合物 (sulfochloride) の 生成することを發見した。1-オクテンと dibenzyl peroxideを $60^{\circ}$ で盟化スルフリルのオクテン溶液を徐々に 滴下して亞硫酸ガスを混合物に通じて dichloroöctaneと その約倍量に近い. $\mathrm{C}_{6} \mathrm{H}_{13} \mathrm{OH}\left(\mathrm{SO}_{2} \mathrm{Cl}\right) \cdot \mathrm{CH}_{2} \mathrm{OH}\left(\mathrm{CH}_{2} \mathrm{Ol}\right)$ $\mathrm{C}_{6} \mathrm{H}_{13}$, m. 57〜 58 孛得た。

\section{結}

語

1933 年以降發達して來た脂肪族化合物のスルホクロル 化について詳述した。就中容易に惯施出來て副反應の少 い Johnson-Sprague 法及び他の硫黄化合物に應用した

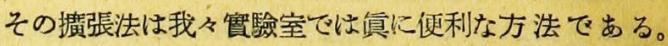
Kharasch 法は現在副反應多く收量す優秀てはなく未だ 研究の餘地が多分に殘されている。これに反して Reed 反㤫の頁の意義は工業的のすのであつて最近 E. I. du Pont 社や Bataafsche petroleun Maatschappij 社の特 許に見るように光線の照射なしに暗黑でる行える觸媒が 多數に發表されている。その操作の簡單なこと〉得られ る種々 sulfochloride の多方面に互る准用價値は盆々發 達するものと思われる。

\section{交献}

1) G. L. Carius, $A n_{\text {. }}, 114,142$ (1860): G. McGowan, J. prakt. Chem., [2] 30, 281 (1884); O. C. Billeter, Ber., 38, 2019(1905); A. Berthoud, Helv. Chim. Acta, 12, 859 (1929); C. S. Marvel, et al., J. Am. Chom. Soc., 51, 1272 (1929); B. Helierich \& A. G. Gnüchtel, Bei.. 71, 712 (1938).

2) P. K. Dutt, J. Chem. Soc., 1924, 1463.

3) E. Chebuliez \& O. Shnauder, Helv. Chim. Acta, 6, 249 (1923).

4) G. Kränzlein \& H. Hopff (to I. G.), D. R. P. 574836 (1933).

5) C. R. Noller \& P. J. Hearst, J. An. Chem. Soc., 70, 3955 (1948); W. A. Proell, et al., Jnd. Eng. Chen, 40, 1129 (1948).

6) Org. Sym., 30, 58 (1950).

7) T. B. Johnson \& T. M. Sprague, Science, $\mathbf{8 3}, 528$ (1936).

8) ibid., J. Am. Chem, Soc., 58, 1348 (1936).

9) B. Rathke, Ber., 14, 1774 (1881).

10) T. M. Sprague \& T. B Johnson, $J$. Am. Chema Soc., 59, 1837 (1937). 
11) H. P. Sterens, J. Chem. Soc., 1902, 79.

12) Org. Syn., 22, 59 (1942).

13) ibid. 21, 37 (1941).

14) H. A. Bruson \& J. W. Easter(to Rohm \& Haas), U. S. P. 2142934 (1939).

15) T. M. Sprague \& T. B. Johnson, J. Am. Chem. Soc., 59, 2439 (1937).

16) T. B. Johnson (to Rohm \& Haas), U. S. P. 2146744 (1939).

17) ibid., U. S. P. 2147346 (1939).

18) J. J. Donleavy. J. Am. Chem. Soc., 58, 1004(1936).

19) K. Folkers, et al., ibid., 63, 3530 (1941).

20) I. B. Douglass \& T. B. Johnson, ibid., 60, 1486 (1938).

21) S. W. Lee \& G. Dougherty, J. Org. Chem., 5, 81 (1940).

22) G. Dougherty \& R. H. Barth (to Heyden Chem. Corp.), U. S. P. $2 \approx 93971$ (1942).

23) M. Battegay \& R. Krebs, Compt. rend., 206, 1262 (1938).

24) T. B. Johnson (to Rohm \& Haas), U. S. P. 2174856 (1939).

25) T. B. Johnson \& J. J. Douglass, J. Am. Chem. Soc., 61, 2548 (1939).

26) F. Asinger, et al., Ber., 75, 42 (1942).

27) F. Asinger \& F. Ebeneder, Ber., 75, 344 (1942).

28) J. Taylor, $J$. Chem. Soc., 1917, 650.

29) H. Bunte, Ber. 7, 646 (1874).

30) H. E. Westlake \& G. Dougherty, $J$. Am. Chem. Soc., 63, 1658 (1941)

31) C. Ziegler \& T. M. Sprague, J. Org. Chem., 16, 621 (1951).

32) H. E. Westlake \& G. Dougherty, J. Am. Chem. Soc., 63, 149 (1942).

33) R. Heuter (to Unichem. Chemikalien Handels A. G.), U. S. P. 2277325 (1942).

34) R. Sperling, J. Chem. Soc., 1949, 1925.

35) E. Lieber \& A. F. Cashman (to Standard Oil Develop. Co.), U. S. P. 2459440 (1949).

36) O. F. Reed (to O. L. Horn), U. S. P. 2043090 (1936); 有機合成化學 9, 101 (1951) 參照

37) ibid., U. S. P. 2174492 (1939).

38) A. L. Fox, et al. (to du Pont \& O. L. Horn), U. S. P. 2228598 (1941).
39) C. F. Reed (to C. L. Hom), U. S. P. 2263312 (1941).

40) H. B. Hass, et al, Ind. Eng. Chem., 29, 1335(1937).

41a) J. Stauff, Z. Klektrochem., 48, 550 (1942); C. A., 37, 5655 (1943).

41b) H. Manneck, Seidensieder Ztg., 73, 21 (1947); Chimie et Ind., 58, 572 (1947).

42) A. L. Fox, et al. (to du Pont), U. S. P. 2202791 (1940).

43) I. G., D. R. P. 715747 (1941)

44) E. I. du Pont, B. P. 553467 (1943).

45) P. Herold, et al. (to General Anilin \& Film Corp.), U. S. P. 2352097 (1944).

43) F. Asinger (to General Anilin \& Film Corp.), U. S. P. 2428733 (1947).

47) W. S. Calcott (to du Pont), U. S. P. 2335259 (1943); E. I. du Pont, B. P. 568102 (1945); I. G., B. P. 511514 (1939); I. G., Belg. P. 443917 (1942).

48) I. G., F. P. 842509 (1939).

49) W. H. Lockwood \& J. L. Richmond (to du Pont), U. S. P. 2193824 (1940).

50) H. J. Schumacher \& J. Stauff, Die Chemie, 55, 341(1942); C. A., 37, 5367(1943); H. Helberger, Die Chemie, 55, 172 (1942); O. A., 37, 79(1943); H. G. Patterson, J. Am. Leather Chemists Assos. 44, 29 (1949) ; L. W. Green, O. T. S. Rep., P. B. 101458 (1950).

51) I. G., D. R. P. 715323 (1941).

52) J. Ross \& D. I. Potter (to Colgate Palmolive Peet Co.), U. S. P. 2304767 (1942).

53) J. B. Roberts, et al. (to du Pont), U. S. P. 2528320 (1950).

54) Colgate Palmolive Peet Co., B. P. 538374(1941); B. P. 538407 (1941).

55) I. G., D. R. P. 721722 (1942).

56) O. O. Henke \& F. M. Schofield (to du Pont), U. S. P. 2333568 (1943).

57) K. Smeykal \& F. Asinger (to I. G.), D. R. P. 711822 (1941).

58) J. Ross \& D. J. Potter (to Colgate Palmolive Peet Co.), U. S. P. 2424420 (1947).

59) J. M. Tinker \& A. L. Fox (to du Pont), U. S. P. 2174507 (1939). 
$60)$ I. G., D. R. P. 717680 (1942).

61) T. E. Dillon (to du Pont), U.S. P. 2408300 (1946).

62) C. O. Henke \& W. H. Lockwoad (to du Pont), U. S. P. 2197800 (1940).

63) A. L. Fox(to du Pont), U.S. P. 2174508 (1939).

64) itid., 2174509 (1939).

65) ibid., 2174500 (1939).

66a) ibid., 2321022 (1943).

66b) ibid., 2351674 (1943).

67) P. Herold, et al. (to General Anilin \& Fim Corp.), U. S. P. 2265163 (1941).

68) J. Ross (to Colgate Palmolive Peet Oo.), U. S. P. 2426383 (1947).

69) D. M. Mc Queen (to du Pont), U.S. P. 22122783 (1940).

70) A. L. Fox (to du Pont), U.S. P. 2345559 (1944).

71) F. Asinger, et al., Ber., 75, 34 (1942).

72) F. Asinger, ibid., 77, 191 (1944).

73) F. Asinger, ibid., 75, 660, 664, 668 (1942).

74) J. H. Helberger, Reichsamt Wirtschaftsausbau, Chem. Ber. Prüf. Nr. 15, P. B. 52013,269 (1942); cit. G. F. Lisk, Ind. Eng. Chem., 41, 1923(1949).

75) I. G., F. P. 853685 (1940).

76) ibid., F. P. 836685 (1940)

77) C. O. Henke \& W. H. Lockwood (to du Pont), U. S. P. 2334764 (1943).

78) J. H. Helberger, et al., Ann., 562, 23 (1949).

79) S. R. Detrick \& W. H. Lockwood (to du Pont), U. S. P. 2462730 (1949).

80) F. F. Rust, et a!. (du Pont), U. S. P. 2519403 $(1950) ; 2543608(1950) ; 2524084(1950) ; 2542578$ (1951).

81) M. S. Kharasch \& H. C. Brown, J. Am. Chem. Soc, 61, 2142 (1939); M. S. Kharasch \& A. T. Read, ilid., 61, 3089 (1939).

82) E. I. du Pont, B. P. 537841 (1941).

83) G. E. Helbrook, et al. (to du Pont), U. S. P. 2333788 (1943).

84) F. Asinger (to General Anilin \& Film Corp.), U. S. P. 2428733 (1947).

85) I. G., F. P. 842509 (1939).

83) O. F. Reed (to C. I. Horn), U. S. P. 2370421 (1945).
(1984).

87) W. S. Calcott (to du Punt), U. S. P. 2335259

88) A. L. Fox (to du Pont), U. S. P. 2319121(1943).

89) E. I. du Poit, B. P. 545521 (1942); A. L. Fox (to du Pont), U. S. P. 2319121 (1943).

90) O. T. S. Rep.; P. B. 70428 ; cit. G. E. Lisk, Ind. Eng. Chem., 42, 1746 (1950).

91) O. T. S. Rep., P. B. 70345 ; cit. G. F. Lisk, Ind. Eng. Chem., 42, 1746 (1950).

92) S. R. Detrick \& L. A. Hamilton (to du Pont), U. S. P. 2392841 (1946).

93) H. M. Grubb (Standard Oil Co. of Indiana), U. S. P. 2374193 (1945).

94) ibid., U. S. P. 2412679 (1949).

95) N. V. de Batarafscie Petroleum Mantschappij, B. P. 628014 (1949); ibid., F. P. 943488 (1949).

93) M. L. Ernsbe g \& \& P. S. Pinkney (to du Pont), U. S. P. 2503253 (1950).

97) M. S. Kharasch \& A. T. Read, J. Am. Chm. Soc, 61, 3089 (1939).

88) R. H. McBee \& O. M. Salls, U. S. P. 18,5,01 (1930).

99) H. O. Brown, Ind. Eng. Chem., 36, 785 (1944); N. Trautz, Z. Elektrochem., 14, 534 (1908).

100) M. S. Kharasch \& H. C. Brown, J. Am, Chem. Sac., 61, 2142, 3432 (1939); 62, 925 (1940).

101) ibid. (to du Pont), U. S. P. 2302228 (1942).

102) M. S. Kharasch (to du Pont), U. S. P. 2383319 (1945); M. S. Kharasch, et al., J. Am. Chem. Soc., 62, 2393 (1940)

103) W. Reppe, et a1. (t) I. G.), D. R. P. 742741 (1943).

104) Colgate Palmolive Peot Co., B. P. 584276 (1942).

105) J. Ross, et al. (to Colgate Palmolive Peet Oo.), U. S. P. 2434746 (1948); G. F. Lisk, Ind. Eng. Chem., 41, 1923 (1949).

103) W. H. Lockwood (to du Pont), U. S. P. 2503279 (1950).

107) M. S. Kharascib \& A. F. Zavist, J. Am. Chem. Soc., 70, 3526 (1948). 